\title{
Attitudes of Jordanian Youth towards Violence against Women
}

\author{
Faisal Ibrahim Mohammad Al-Matalka ${ }^{1} \&$ Mohammad M. Hussainat ${ }^{1}$ \\ ${ }^{1}$ Department of Social Sciences, Ajloun University College, AL-Balqa Applied University, Jordan \\ Correspondence: Faisal Ibrahim Mohammad Al-Matalka, Department of Social Sciences, Ajloun University \\ College, AL-Balqa Applied University, Jordan. Tel: 962-79-526-8899. E-mail: nagpur60@yahoo.com; \\ faisaldr60@hotmail.com
}

$\begin{array}{lc}\text { Received: December 24, } 2012 & \text { Accepted: January 22, } 2013 \quad \text { Online Published: February 28, } 2013 \\ \text { doi:10.5539/ass.v9n3p192 } & \text { URL: http://dx.doi.org/10.5539/ass.v9n3p192 }\end{array}$

\begin{abstract}
This study aimed to examine the attitudes of Jordanian youth towards violence against women. A sample of 2216 youth was randomly selected from all the twelve Governorates in Jordan. A questionnaire was developed to attain the goal of this study, means, standard deviation, $t$ value, and $p-$ value were used. Results showed that Jordanian youth accept violence against women mean $>3,00$, significance level $<0,05$. The findings also showed the most important causes of violence against women as perceived by youth are women not participating in family decisions and lack of religious commitment. It also revealed the most effect of violence against women as seen by youth breaking up of the family and causing continuous worries to family members. The findings also showed that youth do not favor the intervention of officials because they believe that this will cause bad reputation to the family.
\end{abstract}

Keywords: attitude, youth, violence, women, Jordan

\section{Introduction}

In the historical context, violence against women was not a problem for those communities, because they treated women like a commodity owned by the man, which gave him the traditional legislation, and blessed violence against women as a tool of control and education. The situation remained like that until the social changes and education which accompanied the discovery and development that took place in the means of communication, laws and the emergence of concepts of human rights that benefited the prohibition and criminalization of this behavior. However, violence against women still constitutes a danger to the community as a common feature of all societies, where there is hardly any society who do not suffer from this problem, and under different names and pretexts, which derived their justification from ancient cultures handed down between generations, to become the scourge of the modern era, which distorts and kills the spirit of modern humans from all aspects such as the psychological, social, physical, sexual, and economical, and constitutes a threat to society in all sectors and crosses all cultures, borders, religions, education, technology, races, social classes, economic and others.

Violence against women constitutes a violation of human rights, it is also considered as a manifestation of unequal power relations between women and men, which helps the survival of male control over women and prevents women advancement. The issue of violence against the wife falls under the Domestic Violence, which is still not recognized in the community because of the privacy of family relations, and wives cover-up to what violence comes on them, and their sense of shame and disgrace if violence appeared to the public, because consciously or unconsciously the society makes them responsible for what violence falls on them by their husbands. The causes of violence against the wife, lie in the absence of mind, lack of knowledge and understanding, inability to think well or lack of self control (Al-qudah \& Salloum, 2006).

The problem of violence against women formed a black shadow for those communities which practice violence against women, and in spite of human progress in various aspects and what hopes build on it to reduce and dissipate this phenomenon, and with the growth of human values which provides security, peace, democracy and equal opportunity and justice. Violence against women still presents itself to dispel many of the hopes that aspires peoples, dominated by the values of brotherhood, justice and democracy. The last century and the beginning of this century have seen upsurge of violence against women in various areas of social existence, psychological, and economical aspects, and established a presence in various geographical variations, and left their mark on various aspects of life in this era. 
The phenomenon of violence against women for being female, is considered as a global phenomenon experienced by women everywhere and wherever they are, although its forms are different. Despite the high prevalence of this phenomenon, it did not receive sufficient attention and only recently the global feminist movement has begun to emphasize the importance of linking women's rights issues in human rights issues, and consider violence against women as a flagrant violation of their fundamental rights (Mahmoud, 1996).

In the face of challenges posed by this phenomenon on humanity the human mind attempts to explain the dimensions of this phenomenon and its social, psychological, and historical background components. And with the advancement of experiments and originality of the work presented in this area the phenomenon of violence and its analysis are still challenge the scientific mind and inspired the efforts of intellectuals, and mobilize their energies in the search for essence governing the traditions of this phenomenon and those that exist at the origin formed and the reasons for their existence (Gillion, 1999).

Violence against women is considered one of the issues that interest and concern the Jordanian society in general, for the notable increase in the number of battered women, where studies have indicated that women are more vulnerable to violence in its various forms of physical, psychological, sexual, verbal, economic, and social abuse. Furthermore the Jordanian society in private is practicing honor crimes, early marriage, denial of inheritance (Haj yahia, 1998, 2002, ab; Albadayneh, 2005a, 2012; Patterson, 2004; Chalk \& King, 1998).

The Jordanian social culture accepts the use of violence with women as a kind of discipline, and this acceptance is supported by cultural and social norms. However, hurting the individual, or harming them is not accepted religiously (Al-badayneh, 2005 ab). Violence against women in Arab society, in general, can be seen as practicing the masculine power to achieve power and control over the wife or a method of family (wife) discipline (Al-badayneh, 2012).

Studies on violence against women in the Jordanian society pointed out that violence against women is considered to be a familial matter rather than a social or legal issue, speaking about violence within the family particularly violence against women to others than the family members is considered to be shame, stigmatizes the family and damages family dignity , unity and reputation ( Haj- yahia, 1998,2002zb,a+ 2005 Btoush and HajYahia, 2008 : Al - badayneh, 2005a, 2012: Araji \& Carlson, 2001: Matalka, 2012).

Violence against women studies show that, not only men but also women justify and accept violence against women. They also see that using physical abuse against women and wives in particular was not a problem (Matalka, 2009; Haj-Yahia, 2005, Araji \& Carlson, 2001; Khawaja, et al. 2008; Khawaja, 2004).

Violence in the home has generally received high levels of acceptance from both within and outside the family (Faramarzi, et al, (2005); family violence is generally as less serious and less prevalent than other forms of violence (Ross, et al, 1974). People with the family see the violence against women as a private matter; therefore they fail to measure the seriousness and frequency of violence against wife (Goolkasian, 1986). This view has been supported by the belief and practices of the patriarchal society (Haj-Yahia, 2005; Dobash \& Dobash, 1979; Johnson, 1995; Sakall, 2001). Alazmy, et. al (2011) in their study of the attitudes of health care staff towards domestic violence found that high score for both men and women spoke about their agreement for a husband to hit his wife for a good reason, even women had significantly higher mean score than men . The WHO multi country study reported that $53.3 \%$ in the urban and $79.3 \%$ of women in the rural area believed that a man had a right to beat his wife under certain circumstances, such as, when not completing housework adequately, refusing sex, disobeying the husband, or being unfaithful (WHO, 2005).

\subsection{Concept of Violence}

There is difficulty in determining the precise concept of violence, where different terms used in reports, official investigations, and in the debates on social problems, which symbolizes the violence against women in general.

In Jordan several terms have been used by various organizations and agencies so as to indicate the issue of violence, such as violence against women, domestic violence and violence based on gender, domestic violence and other terms that vary depending on the type of service provided by various organizations and agencies working in this sector.

Gender-based violence was defined as violence directed to the person on the basis of sex or gender. It includes any acts that inflict physical, mental, or sexual harm, suffering, the threat of such acts, and deprivation of liberty (Al-Matalka, 2012).

The term violence against women refers to: "any act based on the basis of sex, which leads, or results in, physical, psychological, or sexual harm that falls on woman or girl, and whether the act occurs in private life or public (Al-Matalka, 2009). 
In the national literature domestic violence is defined as the different patterns of behavior by members of the family that causes psychological, physical, verbal, or sexual harm whether occurs directly or indirectly in the context of public or private life.

Violence against women "means any assault against women based on gender, which causes or may cause harm or physical or psychological pain for women, and also includes the threat of such aggression, pressure or arbitrary, deprivation of freedom, whether occurring in the context of public or private life (UNGAR, 1993).

In Jordan the concept of violence is mixed with the concepts of similar meanings and indicators, such as abuse, injury, wound, damage, and causing damage as a term closer to the violence. We found that there is no specific vision for the violence in Jordan, despite a broad consensus that violence exists and is prominent in the community. In spite of that, and as based on the views of many researchers and scholars, violence against women is not considered as a phenomenon within the Jordanian society. It is believed that the reason behind this is the lack of studies on this subject which can give us a clear picture of violence against women in Jordan (National Council for Family Affairs, 2008, 2005), Ameri, (1998), Ratrout \& Itr (2002), Awawdeh (1998), shakhatreh et al (2005), Nasser (1998).

Violence against women is also defined as: any act that occurs on women which causes physical, sexual or psychological abuse or any other form of suffering, such as the threat of such acts or duress, coercion and deprivation of all rights, whether occurs within the framework of family, social or professional relations (Abu-Ghazaleh, 2008).

The concept adopted in this study of violence against women is: any behavior directed towards women, whether occur intentionally or unintentionally, which causes mental, physical, psychological, economical, or social damage to women, including beatings, insults, threats, coercion, deprivation, control, abandonment and jealousy, whether that happens within the context of family, social and or professional relations.

\subsection{Problem of the Study}

The recent years have witnessed a marked increase in the number of cases of violence against women in Jordanian society. This study is trying to answer the following question: What are the attitudes of Jordanian youth towards violence against women? as well as to attempt to identify the causes of violence against women as seen by young people themselves, also to find out young people's awareness of the manifestations of violence and their acceptance to violence, and also their attitudes toward the need of intervention by official authorities on the subject of violence against women in Jordan, and the effects of violence against women as seen by young people themselves.

\subsection{Importance of the Study}

The importance lying behind this study that it is one of the few studies conducted on the attitudes of Jordanian youth towards violence against women to the knowledge of the researcher, and the fact that nearly $65 \%$ of the Jordanian population are young people(, and they slide more important in the renaissance of the community and its development, and also the recommendations that come out of this study and inspired by the views of young people themselves.

\section{Data Collection and Procedures}

A random sample of 2216 youth, both men and women was selected randomly from the Twelve Governorates in Jordan. Data was collected between Feb - 2011 to March - 2012 through face - to face interviews carried out by eighteen researcher and three field supervisors who were trained well for the purpose of collecting data. The response was high in rate $98.2 \%$ due to face - to face interview. Respondents were interviewed in universities, colleges, youth centers, Government and non - Government organizations randomly. The researcher tested the instrument on a sample of 50 cases before the final interviews so that to ensure clarity and understanding of interview questions by the respondents. Respondents consent had been obtained before the actual interview took place. They were also informed about the objectives and purposes of the study.

\subsection{Instrument}

A questionnaire was developed by the researcher based on previous literature and consisted of two parts: The first part included the following variables: gender, age, marital status and level of education. The second part included (34) items consisted of four dimensions, acceptability of violence (13) items, causes of violence (9) items, effect of violence (6) items and intervention of officials dimension (6) items.

\subsection{Hypothesis}

The present study tries to validate the following hypothesis: The Jordanian people accept violence against 
women.

\subsection{Study Questions}

The study tries to answer the following questions:

1) What are the causes of violence against women as perceived by Jordanian youth?

2) What are the opinions of Jordanian youth regarding the effect of violence against women?

3) Do Jordanian youth encourage the intervention of officials when violence against women takes place?

\section{Results}

\subsection{Validity and Reliability}

The entire questionnaires were sent to a group of experts, No. (10), most of them university prof., and were asked to validate the question in regard of its reliability to the present study and its four dimensions. The researcher took the referee remarks which have been approved by $95.2 \%$ of them in to consideration. And a questionnaire consisted of 34 items was finalized.

A Cronbach's Alpha coefficient test was used and it was : 0.76 for acceptability of violence against - women dimension, 0.81 for causes of violence against women dimension, 0.72 for effect of violence against women dimension, 0.79 for intervention of official dimension and 0.85 for all dimensions. All these values are 0.60 which means stability of the tool.

\subsection{Personal Characteristics}

There were 1137 (51.31\%) male and 1079 (48.69 \%) female. The age groups were divided into five groups: $18-24$ years, $\mathrm{N}=378(17.06 \%), 25-31$ years, $\mathrm{W}=509(22.97 \%), 32-38$ years, $\mathrm{N}=707(31.90 \%), 39-46$ years, $\mathrm{N}=$ $434(19.09 \%)$ and 37 years \& more, $\mathrm{N}=199(8.98 \%)$. There were $487(21.95 \%)$ of the respondents are married, 112 (5.05\%) were divorced, 153 (6.91\%) were widow, majority, $\mathrm{N}=1397$ (63.05\%) were single and 67 (3.05\%) were separated.

Their level of education was also measured: 396 (17.87\%) were below secondary, 529 (23.86\%) were secondary, $310(14.23 \%)$ were diploma holder, 094 (26.82\%) were undergraduate, $361(16.27 \%)$ holding graduation degree (Master) and only 21 (0.95) of the respondent were Ph.d holder.

\subsection{Test of Hypothesis and Answering the Question}

In order to test the hypothesis and answering the questions the mean, standard deviation, $\mathrm{t}$ - value and $\mathrm{p}$-value were used. All analyses were carried out using the statistical package for social sciences (spss).

\subsubsection{Test of the Hypothesis: The Jordanian Youth Accept Violence against Women}

Table 1 shows that with the exception of items $(5,6)$ all items obtained arithmetic means $>3.00$ and significance levels $<0.05$, which means that all these are statistically significant and existed. Item (1) which says "It is Accepted that the husband beat his wife', ranked the first with a mean of 4.56, p-value (0.00). Item (10), which says 'Forcing women to conceive without her wish is considered violence was in the second rank with a mean of 4.51 , p-value (0.00). For Item 5 "Taking the salary of women by the husband is considered violence", arithmetic mean was $<3.00$, p-value $(0.00)$ which means that taking the salary of women by the husband is not considered violence. For Item 6"Denial of female inheritance is considered violence", arithmetic means was $<3.00$, p-value $(0.00)$ which means that denial of female inheritance is not considered violence. The table shows that all items scores a mean of 3.88 , and $0.00 \mathrm{p}$-value, which means that the hypothesis 'The Jordanian youth accept violence against women', is accepted by Jordanian youth. 
Table 1.

\begin{tabular}{|c|c|c|c|c|}
\hline Variable & $\begin{array}{l}\text { Arithmetic } \\
\text { Mean (M) }\end{array}$ & $\begin{array}{l}\text { Standard } \\
\text { Deviation } \\
\text { (SD) }\end{array}$ & $\begin{array}{l}\text { T Value of Acceptability } \\
\text { of Violence Dimension } \\
\text { (T) }\end{array}$ & $\begin{array}{l}\text { P-Value of Acceptability } \\
\text { of Violence Dimension } \\
\text { (P) }\end{array}$ \\
\hline $\begin{array}{l}\text { 1-It is accepted that the husband } \\
\text { beat his wife. }\end{array}$ & 4.56 & 0.93 & 17.37 & 0.00 \\
\hline $\begin{array}{l}\text { 2-It is accepted that the father } \\
\text { beat his daughter. }\end{array}$ & 3.94 & 1.04 & 9.31 & 0.00 \\
\hline $\begin{array}{l}\text { 3-It is accepted that the brother } \\
\text { beat his sister. }\end{array}$ & 3.33 & 1.43 & 2.29 & 0.00 \\
\hline $\begin{array}{l}\text { 4-Cursing and yelling at } \\
\text { women's is considers violence. }\end{array}$ & 4.22 & 0.88 & 14.45 & 0.00 \\
\hline $\begin{array}{l}5 \text {-Taking the salary of women is } \\
\text { considered violence. }\end{array}$ & 2.81 & 1.28 & 1.51 & 0.00 \\
\hline $\begin{array}{l}\text { 6-Denial of female inheritance is } \\
\text { considered violence. }\end{array}$ & 2.79 & 1.70 & 1.30 & 0.20 \\
\hline $\begin{array}{l}\text { 7-Denial of women's } \\
\text { participation in social events is } \\
\text { considered violence. }\end{array}$ & 4.19 & 1.05 & 11.78 & 0.00 \\
\hline $\begin{array}{l}\text { 8-Depriving } \\
\text { education } \\
\text { violence. }\end{array}$ & 3.97 & 0.86 & 11.77 & 0.00 \\
\hline $\begin{array}{l}\text { 9-Forcing wife for sex is } \\
\text { considered violence. }\end{array}$ & 4.21 & 1.34 & 9.41 & 0.00 \\
\hline $\begin{array}{l}\text { 10-Forcing women to conceive } \\
\text { is considered violence. }\end{array}$ & 4.51 & 0.69 & 22.72 & 0.00 \\
\hline $\begin{array}{l}\text { 11-Threatening wife of second } \\
\text { marriage is considered violence. }\end{array}$ & 4.10 & 0.80 & 14.38 & 0.00 \\
\hline $\begin{array}{l}\text { 12-Desertion of women is } \\
\text { considered violence. }\end{array}$ & 3.97 & 1.11 & 9.07 & 0.00 \\
\hline $\begin{array}{l}\text { 13-The issue of violence against } \\
\text { women is a matter of } \\
\text { community }\end{array}$ & 3.77 & 0.67 & 11.98 & 0.00 \\
\hline All grouped items & 3.88 & 0.77 & 10.37 & 0.00 \\
\hline
\end{tabular}

\subsubsection{Answering the Questions}

\section{Q1: What are the causes of violence against women as perceived by Jordanian youth?}

Table 2 shows that all items obtained arithmetic means $>3.00$ and significance levels $<0.05$, which means that all these are statistically existed and Jordanian youth considered these items as causes of violence against women in the Jordanian society. Item (22) which says "Non-participation of women in family decisions leads to violence", ranked in the first place with a mean of 4.00.and p-value (0.00). Item (21), which measures if lack of religious commitment leads to violence against women, was in the second rank with a mean of 3.94, and p-value (0.00), next ranks are no. $16,20,15,17,14,19,18$, respectively. 
Table 2 .

\begin{tabular}{|c|c|c|c|c|}
\hline Variable & $\begin{array}{l}\text { Arithmetic } \\
\text { Mean (M) }\end{array}$ & $\begin{array}{l}\text { Standard } \\
\text { Deviation } \\
\text { (SD) }\end{array}$ & $\begin{array}{l}\text { T-Value of Causes of } \\
\text { Violence Dimension } \\
\text { (T) }\end{array}$ & $\begin{array}{l}\text { P-Value of Causes of } \\
\text { Violence Dimension } \\
\text { (P) }\end{array}$ \\
\hline $\begin{array}{l}\text { 14-Beating women is a sign of } \\
\text { masculinity. }\end{array}$ & 3.77 & 0.86 & 7.08 & 0.00 \\
\hline $\begin{array}{l}\text { 15-Clan and relatives interference } \\
\text { leads to violence against women. }\end{array}$ & 3.88 & 0.34 & 20.36 & 0.00 \\
\hline $\begin{array}{l}16 \text {-Beating women is considered to } \\
\text { be an educational way. }\end{array}$ & 3.91 & 0.77 & 8.97 & 0.00 \\
\hline $\begin{array}{l}\text { 17-Lack of constructive dialogue } \\
\text { leads to violence against wife. }\end{array}$ & 3.87 & 0.74 & 8.87 & 0.00 \\
\hline $\begin{array}{l}\text { 18-Some customs and traditions lead } \\
\text { to violence against women. }\end{array}$ & 3.74 & 0.36 & 16.37 & 0.00 \\
\hline $\begin{array}{l}\text { 19-Wife endures violence for the sake } \\
\text { of children and family cohesion. }\end{array}$ & 3.74 & 0.95 & 10.13 & 0.00 \\
\hline $\begin{array}{l}\text { 20- Lack of education leads to } \\
\text { violence against women. }\end{array}$ & 3.89 & 0.41 & 16.84 & 0.00 \\
\hline $\begin{array}{l}\text { 21-Lack of religious commitment } \\
\text { leads to violence against women. }\end{array}$ & 3.94 & 0.54 & 13.06 & 0.00 \\
\hline $\begin{array}{l}\text { 22-Non-participation of women in } \\
\text { family decisions leads to violence. }\end{array}$ & 4.00 & 0.43 & 17.69 & 0.00 \\
\hline All grouped items & 3.86 & 0.48 & 13.66 & 0.00 \\
\hline
\end{tabular}

\section{Q2: What are the opinions of Jordanian youth regarding the effect of violence against women?}

Table 3 shows that all items obtained arithmetic means $>3.00$ and significance levels $<0.05$, which means that all these are statistically existed and the Jordanian youth considered it as outcome effects of violence against women in Jordan. Item (25) which says "Hitting the women leads to the breakup of the family", ranked first with a mean of 4.02, and p-value 0. 00. Item (24), which measures if violence against women causes worries to family members, was in the second rank with a mean of 4.01., and p-value 0.00 . Next ranks are 26, 23, 27, and 28, respectively.

Table 3 .

\begin{tabular}{lcccc}
\hline \multicolumn{1}{c}{ Variable } & $\begin{array}{c}\text { Arithmetic } \\
\text { Mean (M) }\end{array}$ & $\begin{array}{c}\text { Standard } \\
\text { Deviation } \\
\text { (SD) }\end{array}$ & $\begin{array}{c}\text { T-Value of Effects of } \\
\text { Violence Dimension } \\
\text { (T) }\end{array}$ & $\begin{array}{c}\text { P-Value of Effects of } \\
\text { Violence Dimension } \\
\text { (P) }\end{array}$ \\
\hline $\begin{array}{l}\text { 23- Violence against women affects } \\
\text { children within the family. }\end{array}$ & 3.89 & 0.86 & 7.08 & 0.00 \\
$\begin{array}{l}\text { 24- Violence against women causes } \\
\text { worried to family members. }\end{array}$ & 4.01 & 0.34 & 20.36 & 0.00 \\
$\begin{array}{l}\text { 25- Hitting the women leads to the } \\
\text { breakup of the family }\end{array}$ & 4.02 & 0.77 & 8.97 & 0.00 \\
$\begin{array}{l}\text { 26- Violence against women leads } \\
\text { to health problems. }\end{array}$ & 3.95 & 0.74 & 8.87 & 0.00 \\
$\begin{array}{l}\text { 27- Violence against women leads } \\
\text { to psychological problems }\end{array}$ & 3.86 & 0.36 & 16.37 & 0.00 \\
$\begin{array}{l}\text { 28- } \begin{array}{l}\text { The issue of violence against } \\
\text { women is a threat to the entire } \\
\text { community. }\end{array} \\
\begin{array}{l}\text { All grouped items } \\
\hline\end{array}\end{array}$ & 3.85 & 0.59 & 14.89 & 0.00 \\
\hline
\end{tabular}




\section{Q3: Do Jordanian youth encourage the intervention of officials when violence against women takes place?}

Table 4 shows that all items obtained arithmetic means $>3.00$ and significance levels $<0.05$, which means that all these are statistically existed .Item (29) has arithmetic means 3.60 and p-value 0.00 which means that violence against women is considered as private matter and must not be tampered with any party. Item (30) has arithmetic means 3.87 and p-value 0.00 which means that the battered women must recourse to official. Item (31) has arithmetic means 3.92 and p-value 0.00 which means that asylum to official by battered women causes bad reputation to the family. Item (32) has arithmetic means 3.81 and p-value 0.00 which means that resort to official by battered women leads to divorce. Item (33) has arithmetic means 3.81 and p-value 0.00 which means that the issue of violence against women is a matter for government agencies only. Item (34) has arithmetic means 3.79 and p-value 0.00 which means that violence against women is a crime requiring official intervention.

Table 4

\begin{tabular}{lcccc}
\hline \multicolumn{1}{c}{ Variable } & $\begin{array}{c}\text { Arithmetic } \\
\text { Mean (M) }\end{array}$ & $\begin{array}{c}\text { Standard } \\
\text { Deviation } \\
\text { (SD) }\end{array}$ & $\begin{array}{c}\text { T-Value of Intervention } \\
\text { of Official Dimension } \\
\text { (T) }\end{array}$ & $\begin{array}{c}\text { P-Value of Intervention } \\
\text { of Official Dimension } \\
\text { (P) }\end{array}$ \\
$\begin{array}{l}\text { 29-Violence against women is a } \\
\text { private matter that must not be } \\
\text { tampered with any party. }\end{array}$ & 3.60 & 0.77 & 6.88 & 0.00 \\
$\begin{array}{l}\text { 30-The battered women must } \\
\text { recourse to official. }\end{array}$ & 3.87 & 0.66 & 10.49 & 0.00 \\
$\begin{array}{l}\text { 31-Asylum to official by battered } \\
\text { women causes bad reputation to the } \\
\text { family. }\end{array}$ & 3.92 & 0.51 & 14.25 & 0.00 \\
$\begin{array}{l}\text { 32-Resort to official by battered } \\
\text { women leads to divorce. }\end{array}$ & 3.81 & 0.71 & 9.34 & 0.00 \\
$\begin{array}{l}\text { 33-The issue of violence against } \\
\text { women is a matter for government }\end{array}$ & 3.81 & 0.53 & 12.33 & 12.00 \\
$\begin{array}{l}\text { agencies only. } \\
\text { 34-Violence against women is a } \\
\text { crime requiring official intervention. }\end{array}$ \\
\begin{tabular}{l} 
All grouped items \\
\hline
\end{tabular}
\end{tabular}

\section{Discussion and Suggestions}

\subsection{Acceptance of Violence}

The purpose of this study was to examine attitudes of Jordanian youth towards violence against women, and to identify the causes of violence against women as perceived by Jordanian youth. It also aimed to examine how far the Jordanian youth accept violence against women and what they feel about the effect of this violence on women as well as the family. And also, it measures their attitudes toward interferences of Governmental agencies when violence against women occurs.

The findings show that there is significant acceptance of violence against women by Jordanian youth. This may give us clear picture regarding the dominant culture in the Jordanian society. Violence against women has increased during the past few years. Most of the respondents accepted that husband, fathers and the brother beat women, and they do not see that taking the salary of women and deprivation of her right from inheritance to be considered as violence against her. Table (1) gives us clear picture that the Jordanian youth do accept violence against women.

The findings are congruent with other researches done by (Khawaja, 2004, Al - badayneh, 2012, Haj - yahia, 2000). Therefore, we may say that the increasing phenomenon of violence against women in the Jordanian society is attributed to the dominant thinking and mentality prevailing among men and women which accept the violence against women as a part of the culture. The findings are also congruent with other studies which showed that in respect of the outcome and results of violence, still men and women justified and accepted violence 
against women (Khawaja, et al, 2008, Oweis, et al. 2009, Araji \& Carlson, 2001, Al-badayneh, 2012).

\subsection{Causes of Violence}

The finding also shows that in respect of causer of violence as perceived by youth all items scores arithmetic mean $>3.00$ and significant level $<0.005$

This shows that most of the respondents see that violence occurs within the family when women are not involved in decisions taking in the family, lack of religious commitment, violence is considered as an educational way, lack of education (Ignorance), interference of clan and relatives, lack of constructive dialogue among couple, a sign of masculinity, for the sake of children and the customs and traditions which lead to violence against women's of violence against women from Jordanian youth's point of view.

The finding also shows the mentality of the hierarchy society that is dominant in the Jordanian culture. It also shows that violence against women is deeply rotted in the Jordanian social culture. "The presence of widespread cultural and social norms that support violence against women is fostered by cultural and social expectations that support roles of men and women, which generally devalue woman" (Al-badayneh, 2012).

\subsection{Effect of Violence}

The finding showed the effect of violence against women as perceived by Jordanian youth. They feel that the most important outcome of violence against women as presented in table (3) was breakdown of the family, causing worry among family members, health problems and it threats the entire community. We notice here that the respondent are well aware of the consequences of violence against women whether these effects cause harm to an individual or to the community as a whole, but they still accept the violence. This may be due to the way these youth were brought up within the family as well as the community they belong to, which approve and adopt violence against women as a way of education and a sign of masculinity man must adopt.

The findings of this study are congruent with other studies carried out by (Araji \& Carlson, 2001; Haj-yahia. 1998 b, 2005; Zurak, et al, 1997; Al-Badayneh, 2005, b; Matalka, 2009, 2112).

\subsection{Intervention of Officials}

The findings of this study showed that, all items which measure youth opinions and attitudes towards if they support the idea of reporting the cases of violence against women to official and the necessity of interferences by official agencies against the violence, the results revealed that youth are not in agreement with these items, arithmetic means $>3.00$, significant levels $<0.05$, (P. value for all items $=0.00$ ), which means that all these items are significantly present.

The findings showed that the Jordanian youth believe that asylum to official by battered will cause a bad reputation to the family, lead to divorce, and violence against women it is a matter for government agencies only, it is a crime requiring official intervention, and violence against women is a private matter that must not be tampered with any party. "This situation is consistent with gender roles and status expectations within the Jordanian social system; in order to avoid such consequences, women have to comply with social and cultural rules that justify violence as part of women discipline and husband authority. Women usually deny their fear and minimize the seriousness of the situation; and they are shameful and stigma (Al-Badayneh,2012).Other literatures showed that interference in family problems particularly those concerning women is considered to be a private matter and interference in such matters is unacceptable and rejected by the society (Matalka, 2009, 2012, Al - badayneh, 2005, 2012; Araji \& Carlson, 2001, Haj-Yahia, 2002b, 2005).

\section{Conclusion and Suggestions}

Violence against women is one of the most widespread human rights abuses and problem not only in Jordan but in the whole world. Violence against women in the Jordanian society as shown in this study can be understood in social and cultural context," The patriarchal ideology and system, violence against women is one way of maintaining power, control, and dominance of husband over wife. Gender inequality can be partially attributed to the gender status and there is a need to break down the taboo that violence is a private matter." We conclude that there is a need for a comprehensive response in order to change the behavior and thinking of the Jordanian youth and their attitudes towards violence against women in the Jordanian society through educating youth and the people of Jordan on the impact of violence against women and the whole society.

The researchers suggest the following measures so that they may help in minimizing and curbing the increasing number of violence against women in the Jordanian society:

1) Domistic violence should be taught in university as a separate subject and on under graduation level. 
2) Teaching the religious belief which prohibited violence against women in school.

3) Further research must investigate the cultural elements that boast or enhance violence against women.

4) Collective effort should be sustained to promote general understanding of gender equality and the empowerment of women.

\section{References}

Abu-Ghazaleh, H. (2008). Violence against women: A shared idea for changing. The polices, 2. The National council for family affairs, Amman, Jordan.

Alazmy, S., Alotaibi, D., Atwan, A., Kamel, M., \& El-Shazly, M. (2011). Gender difference of Knowledge and attitude of primary health care staff towards domestic violence. Alexandria Journal of Medicine, 47, 337-341. http://dx.doi.org/10.1016/j.ajme.2011.07.018

Al-Badayneh, D. (2004). National plan for protection of the Jordanian family from violence. Unpublished manuscript. Amman, Jordan: The national council for family Affairs.

Al-Badayneh, D. (2005a). National framework for the protection from family violence. Amman, Jordan: The national council for family Affairs (NCFA).

Al-Badayneh, D. (2005b). Violence in Jordan from home to the road. Violence in Universities Seminar, Mu'tah University, Jordan.

Al-Badayneh, D. (2012). Violence against women in Jordan. Journal of family violence, 27(5), 369-379. http://dx.doi.org/10.1007/s10896-012-9429-1

Al-Matalka, F. (2009). The Health Impact of the Violence against Women in Aqaba Region - Jordan, Paper presented at the International Sociological Association, Research Committee on Sociology of Health (RC 15), Mid-term Conference, Health for All: Opportunities and Challenges. Jaipur, India, September, 21-23.

AL-Matalka, F. (2012). Violence against Women in Aqaba city -Jordan. Studies in Sociology. Department of Sociology. University of Rajasthan, Jaipur, India.

Al-Qudah, M., \& Salloum, W. (2006). Domestic violence and its effect on the health of the family. Derassat: shariah \& law, 33(1), 138-159.

Al-Ratrout, F., \& Itter, H. (2002). The Expected Social Impact to the Violent Woman Protection Project House in Jordan, From Academic and Social Experts Point of View, Social Field Study, Ministry of Social Development, Amman, Jordan.

Araji, S. K., \& Carlson, J. (2001). Family violence including crimes of honor in Jordan: Correlates and perceptions of seriousness. Violence against Women, 7, 586-621. http://dx.doi.org/10.1177/10778010122182613

Awawdeh, A. (1998). Violence against Wife in the Jordanian Society. Unpublished M .A, thesis, Jordan University. Amman, Jordan.

Btoush, R., \& Haj-Yahia, M. (2008). Attitudes of Jordanian society toward violence against women. Journal of Interpersonal violence, 23(11), 1531-1554. http://dx.doi.org/10.1177/0886260508314313

Dobash, R., \& Dobash, R. P. (1979). Violence against wives. New York: Free press.

Faramarzi, M., Esmailzadeh, S., \& Mosavi, S. (2005). A comparison of abused and non - abused Women's definitions of domestic violence and attitude to acceptance of male dominance. European Journal of Obstetrics \& Gynecology and Reproductive Biology, 122, 225-231. http://dx.doi.org/10.1016/j.ejogrb.2004.11.047

Gillion, A. (1999). Violence and Education. (Assad Ali, Translation). College of Education, Kuwait University, Kuwait.

Goolkasian, G. (1986). Confronting domestic violence: the role of criminal court judges. Washington, D.C.: U.S. Department of Justice, National Institute of Justice.

Haj-Yahia, M. M. (1998a). Beliefs about wife beating among Palestinian women: the influences of their patriarchal ideology. Violence against women, 4(5), 533-558. http://dx.doi.org/10.1177/1077801298004005002

Haj-Yahia, M. M. (1998b). A patriarchal perspective of beliefs about wife beating among Palestinian men from the west Bank and the Gaza Strip. Journal of family Issues, 19(5), 595-621. 
http://dx.doi.org/10.1177/019251398019005006

Haj-Yahia, M. M. (2000a). Patterns of violence against engaged Arab women from Israel and some psychological implications. Psychology of Women Quarterly, 24(3), 209-219. http://dx.doi.org/10.1111/j.1471-6402.2000.tb00202.x

Haj-Yahia, M. M. (2000b). Violence Against women and battering in the sociocultural context of Arab society. Family process, 39(2), 237-255. http://dx.doi.org/10.1111/j.1545-5300.2000.39207.x

Haj-Yahia, M. M. (2005). Can peoples patriarchal ideology predict their beliefs about violence against women? The case of Jordanian men. Journal of community psychology, 33(5), 545-567. http://dx.doi.org/10.1002/jcop.20068

Johnson, M. (1995). Patriarchal terrorism and common couple violence: two forms of violence against women. Journal of marriage and the family, 57, 283-294. http://dx.doi.org/10.2307/353683

Khawaja, M. (2004). Domestic violence in refugee camps in Jordan. International Journal of Gynecology \& Obstetrics, 86(1), 67-69. http://dx.doi.org/10.1016/j.ijgo.2004.04.008

Khawaja, M., Lions, N., \& El-Roueibeb, Z. (2008). Attitudes of men and women towards wife beating: Finding from Palestinian refugee camps in Jordan. Journal of family violence, 23, 211-218. http://dx.doi.org/10.1007/s10896-007-9146-3

Mahmud, N. (1996). Crimes against Honour: Women in International Refugee Law. Journal of Refugee Studies, 9(4), 367-382. http://dx.doi.org/10.1093/jrs/9.4.367

Nasser. (1998). Violence against Women in the Jordanian Society. The Demographic Characteristics, The Victims and Perpetrators, The Human Forum for Women's Rights, Field Study, Human Meeting For Woman Rights. Amman, Jordan.

Oweis, A., Gharaibeh, M., Al-Natour, A., \& Froelicher, E. (2009). Violence against women: unveiling the suffering of women with low income in Jordan. Journal of Transcultural Nursing, 20, 69-76. http://dx.doi.org/10.1177/1043659608325848

Rossi et al. (1979). The seriousness of crimes: normative structure and individual differences. American sociological Review, 39, 224-237. http://dx.doi.org/10.2307/2094234

Sakall, N. (2001). Beliefs about wife beating among Turkish college students: the effects of patriarchy, sexism , and sex differences. Sex Roles, 44, 599-610. http://dx.doi.org/10.1023/A:1012295109711

Shakhatreh, Gharaibeh, M., Ewes, A, \& Shtaewy, M. (2005). The Family Violence in Jordan, The Knowledge, Directions and Reality, The National Council for Family Affairs with Co-operation with British Cultural Council, Amman, Jordan.

The National Council for Family Affairs, World Health Organization. (2008, 2005). Health and Violence, Amman, Jordan.

UN General Assembly. (1993). Declaration of the Elimination of Violence against Women. Proceeding of the 85th Plenary Meeting. Geneva: UN, Dec. 20. 